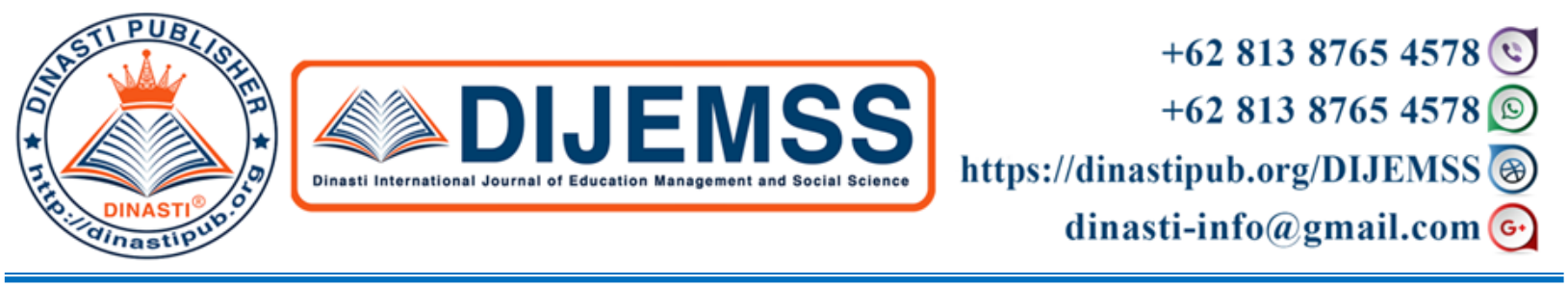

INFLUENCE OF LEADERSHIP, COMPENSATION \& COMMITMENT TO EMPLOYEE PERFORMANCE IN PASAR MOBIL KEMAYORAN MANAGEMENT (PPMK)

Herdina Irdaningsih
${ }_{1,2,3)}$ Mercu Buana University, Jakarta, Indonesia

ARTICLE INFORMATION

Received: $5^{\text {th }}$ June 2020

Revised: $25^{\text {th }}$ June 2020

Issued: $22^{\text {th }}$ August 2020

Corresponding author:

First Author

Email:

55117320046@mercubuana.ac.id parwoto.parwoto@mercubuana.ac.id

ahmad.badawi@mercubuana.ac.id

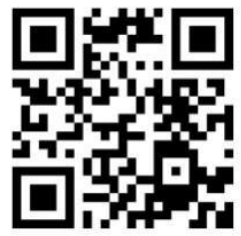

DOI:10.31933/DIJEMSS
Abstract: This study aims to examine and analyze the effect of leadership, compensation, commitment, and career development on employee performance at the Pasar Mobil Kemayoran Management (PPMK). In this study, the authors used a descriptive research method using a quantitative approach. In this study, the ordinal measurement method uses a Likert scale which is used to measure the attitudes, opinions and perceptions of a person or group of people about social phenomena. Based on the results of the study showed that the value of Fcount is 11,644 with sig. of 0,000 while the value of Ftable of 2.38. Because Fcount is greater than Ftable $(11,644>2.38)$ and the value of sig. $0,000<0.05$ then $\mathrm{H} 0$ is rejected and $\mathrm{Ha}$ is accepted, so it can be concluded that the leadership variable (X1).

KeyWords: Leadership, compensation, commitment and employee performance

\title{
INTRODUCTION
}

Human resources are one of the resources in the organization including all people who carry out activities. Human resources are the only resources that have the intellect, feelings, desires, abilities, skills, knowledge, encouragement, power and work as well as the only resources that have ratio, taste and intention. All potential human resources are very influential on the efforts of the organization in achieving its goals. Employee management and human resources are very important for the company in managing, managing and improving employee performance so that it can function productively to achieve company goals. Every company always expects its employees to work as efficiently as possible, so as to maintain the viability of the company, Performance review, also known as performance appraisal, performance evaluation, performance rating, performance assessment, employee evaluation, is basically the process used by companies to evaluate job performance. 
If done correctly, this will provide important benefits for employees, supervisors, HR departments, and companies. Managers and supervisors must evaluate performance for what actions will be taken. The HR Department uses information collected through performance evaluations to evaluate the success of recruitment, selection, orientation, placement, training and other activities.

Performance Appraisal (PA) is a formal system that is used in certain periods of time to assess an employee's work performance. In addition, performance appraisal can function to identify, observe, measure, record, and see the strengths and weaknesses of employees in doing work. The use of performance appraisals can improve employee performance. Performance appraisals are truly designed in such a way as to help companies achieve organizational goals and motivate employee performance. The purpose in using this performance appraisal is to improve the work performance of employees. Performance appraisals are truly designed in such a way as to help companies achieve organizational goals and motivate employee performance.

The mission of the Pasar Mobil Kemayoran Management (PPMK) includes: carrying out in carrying out the tasks as the Pasar Mobil Kemayoran Management (PPMK) according to function, planning business strategies, compiling a program of activities that are adjusted to the budget, Implementing services to the tenants, implementing construction and maintenance in the region Pasar Mobil Kemayoran, increase revenue Pasar Mobil Kemayoran, the implementation of cooperation with third parties in the context of business development in the Pasar Mobil Kemayoran area, and the implementation of security and security. In its mission, the Pasar Mobil Kemayoran Management must be able to create good environmental conditions for human resources in order to avoid conflicts in achieving the mission.

From the table above according to employees that the company is not fair in carrying out performance appraisals of $87.5 \%$, while $12.5 \%$ rate fair in assessments, as well as for promotion While $57.5 \%$ of guarantees given by the company to employees are inadequate and $42.5 \%$ of employees feel that the company provides adequate guarantees. In terms of developing opportunities as much as 50\% feel given and the remaining $50 \%$ feel not given the opportunity to develop.

Leadership is the activity or art of influencing others to want to work together based on the person's ability to guide others in achieving the goals desired by the group. Leadership is a central theme in management that is always interesting to be observed and discussed, this is due to the influence of a leader who will be a benchmark in looking at the life and development of an organization. Leaders have a very strategic and important role in efforts to achieve the mission, vision and goals of an organization.

Like the definition of leadership, leadership theories can be found in various ways. According to Mark Walker's in Goethals and Sorenson (2006: 55-57) in the study of leadership has developed a variety of leadership theories, including: traits theory, behavior theory, and contingency theory (Situational Theory / Situational Theory) ), transformational theory (Transformational Theory), and transactional theory (Transactional Theory).

In the times, the leadership was scientifically then developed, together with the growth of scientific management (scientific management) which was pioneered by scientist Frederick W. Taylor in the early 20th century and then developed into a leadership science (Kartono, 2010).

In an effort to realize organizational goals, leaders cannot work alone but need personnel who are able to work together. The contribution of each employee in supporting the success of the organization will depend on the leaders themselves in influencing their employees. Mary Coulter (2012: 488) said that: "Leadership is what leaders do. It's the process of leading a group 
and influencing that group to achieve it's goals ". "Leadership is what leaders do is the process of leading a group and influencing it to achieve goals."

Leadership (leadership) can be said as a way of a leader (leader) in directing, encouraging and managing all elements of the organization to achieve a desired organizational goals so as to produce maximum employee performance. The author conducted a pre-survey and stated that the existing leaders were not optimally carrying out their functions appropriately. Based on the table above $60 \%$ of employees stated that the leader only gave orders without being able to do coaching, the rest stated otherwise. The leader did not heed the advice of employees for the remaining $57.5 \%$ stated otherwise. In addition, employees who stated that the Leader did not apply an authoritarian approach to decision making by $37.5 \%$ stated authoritarian, the rest stated otherwise. The leader always assesses subjectively of employees by $37.5 \%$ declaring valuations subjectively while the remaining $62.5 \%$ states not subjectively in evaluating employees. The leader was unable to make the work atmosphere comfortable as much as $62.5 \%$, while the rest stated otherwise.

Based on the compensation survey, $55 \%$ of employees feel that they are given a salary according to the workload, while the remaining $45 \%$ feels the opposite. As many as $75 \%$ of companies provide salary on time and the rest are not given salary on time. The company, according to $42.5 \%$ of employees, has given bonuses according to work performance, while $57.5 \%$ felt they did not get bonuses according to performance. According to $45 \%$ of employees the salary is deducted according to the mistakes made and the rest of employees feel the salary deduction is not in accordance with the mistakes they made.

Based on the commitment survey as many as $45 \%$ of sure employees spent careers in the company where they work now the rest are not sure. As many as 60\% felt the company's problem was the employee's problem the rest stated no. As many as $75 \%$ of employees said that being on time makes work lighter, the rest feels not. Employees who are willing to come to the office during holidays because there are urgent problems as much as $72 \%$ the remaining $27.5 \%$ said no.

The purpose of this study is to analyze whether leadership. compensation, and commitment affect both partially and simultaneously on the performance of employees in the Pasar Mobil Kemayoran Management. This research is expected to be used by management as a material consideration for making policies in the field of human resource development. Besides this research is expected to be a reference material for further research.

\section{THEORITICAL REVIEW}

\section{Leadership}

Hemphill \& Coons (Gary Yulk, 2009: 4), explained that Leadership is an individual behavior that directs group activities to achieve common goals.

Burns (Gary Yulk, 2009: 4), explained that leadership is carried out when someone mobilizes institutional, political, psychological and other resources to generate and involve the motivation of followers.

\section{Compensation}

Compensation is anything that is received by employees as a remuneration for the work done. In working every employee is willing to drain energy, time and thoughts by hoping to get rewarded. Seen from the purpose of providing compensation has two interests, namely the interests of employees and interests of the company. 
According to Hendry Simamora (2015: 442) Compensation is what is received by employees in exchange for their contribution to the organization, in addition compensation includes financial rewards and tangible services and benefits received by employees as part of employment relations. Components in compensation are divided into two, namely direct compensation and indirect compensation. Direct compensation consists of payments received by someone in the form of salary, wages, bonuses, and commissions. Indirect compensation, also called benefits, includes all financial rewards that are not covered by direct compensation.

\section{Commitment}

According to Robbins in Anindya (2011) commitment to the organization is a situation where an employee sides with a particular organization and its goals and desires to maintain membership in the organization.

Commitment is an attitude that reflects the extent to which an individual or employee knows and is bound to his organization (Griffin, 2004: 15).

\section{The performance}

Every company wants its employees to have high performance. The basic part of management through goals is the assumption that employee performance can be improved if employees know what is expected of them, when they are allowed to participate in the process of setting expectations.

More specifically according to Gibson et. al (2013: 363) said that "The main purpose of the award program is to attract capable people to join the organization, keep workers coming to work, and motivate workers to achieve high performance." Because employees want to be cared for and also appreciated while working, all forms of attention given by the company to their employees will make employees feel valued by the company, and thanks to that attention can increase their motivation to work.

\section{FRAMEWORK OF THINKING}

The framework for this research is as presented in the following figure:

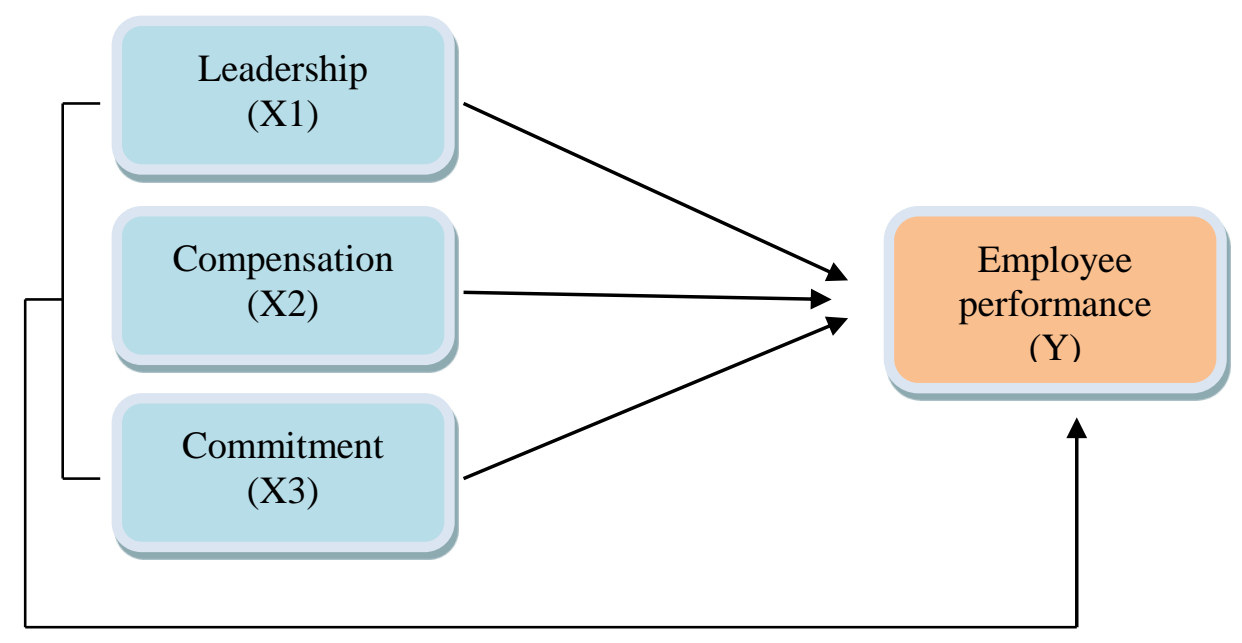

Source: Processed Literacy (Yulk, Simamora, Griffin, \& Gibson)

Figure 1: Research Hypothesis Framework 


\section{HYPOTHESIS}

a. Hypothesis $1(\mathrm{H} 1)$ : There is an influence of leadership on employee performance in the Pasar Mobil Kemayoran Management.

b. Hypothesis 2 (H2): There is an effect of Compensation on the Performance of employees in the Pasar Mobil Kemayoran Management.

c. Hypothesis 3 (H3): There is an effect of Organizational Commitment on employee performance in the Pasar Mobil Kemayoran Management.

\section{RESEARCH METHODE}

\section{Research Type / Research Design}

Research design is all the processes required in planning and conducting research. The research design includes the collection and analysis of data in research. The design in this study uses quantitative descriptive, which is research that aims to find out the relationship between the independent variables and the dependent variable. The data analysis used is multiple linear analysis method, with the help of Statistical Product and Service Solution (SPSS) Version 2.4.

The dependent variable used in this study is employee performance. The independent variables used in this study are leadership, compensation and commitment. The independent variable used in this study is employee performance.

\section{Population and Research Samples}

Population is the whole object or subject that is in an area and fulfills certain conditions related to the research problem, or the whole unit or individual in the scope to be studied. The population of this study is employees who work in various companies, amounting to 60 people.

According to Arikunto (2012: 104) if the total population is less than 100 people, then the total sample is taken, but if the population is greater than 100 people, then it can be taken 10$15 \%$ or $20-25 \%$ of the total population. Based on data received by researchers the number of employees of the Pasar Mobil Kemayoran Management is not greater than 100 respondents, the authors take $100 \%$ of the total population that is as many as 75 respondents. Thus the use of the entire population without having to draw research samples as observation units is referred to as census techniques.

\section{Data Types and Sources}

This study uses primary data and secondary data. Primary data in the form of interviews, questionnaires distributed to respondents and documentation. While secondary data in the form of literature studies, manuals and notes relating to the research variables to be examined, and other data relevant to research.

\section{RESULTS AND DISCUSSION}

\section{Descriptive Statistics of Research Variables}

To get an overall picture of the variables used in this study both the dependent variable and the independent variable, a descriptive statistical analysis is first performed which includes the mean (standard), standard deviation, and extreme values (maximum and minimum values).

Table 1. Descriptive Statistical

\begin{tabular}{|l|c|c|c|c|c|}
\hline \multicolumn{7}{|c|}{ Statistics } \\
\hline & & leadership & Compensation & commitment & the performance \\
\hline $\mathrm{N}$ & Valid & 75 & 75 & 75 & 75 \\
\hline
\end{tabular}




\begin{tabular}{|c|c|c|c|c|}
\hline Missing & 0 & 0 & 0 & 0 \\
\hline The mean & 23.8267 & 49.6267 & 60.0267 & 53.3467 \\
\hline Std. Error of Mean & .18636 & .72826 & .75599 & .14886 \\
\hline Median & 24.0000 & 49.0000 & 60.0000 & 53.0000 \\
\hline Mode & 24.00 & 60.00 & 59.00 & 53.00 \\
\hline Std. Deviation & 1.61390 & 6.30695 & 6.54707 & 1.28918 \\
\hline Variance & 2,605 & 39,778 & 42,864 & 1,662 \\
\hline Skewness & 5,323 & .140 & -956 & 2,080 \\
\hline Std. Error of Skewness & 277 & 277 & 277 & 277 \\
\hline Kurtosis & 33,747 & -817 & .965 & 5,115 \\
\hline Std. Error of Kurtosis & .548 & .548 & .548 & .548 \\
\hline Range & 13:00 & 24.00 & 27.00 & $7: 00$ \\
\hline Minimum & 10:00 PM & $36: 00$ & 43.00 & 51.00 \\
\hline Maximum & 35.00 & 60.00 & 70.00 & 58.00 \\
\hline Sum & 1787.00 & 3722.00 & 4502.00 & 4001.00 \\
\hline \multirow[t]{3}{*}{ Percentiles } & 23.0000 & 44.0000 & 58.0000 & 53.0000 \\
\hline & 24.0000 & 49.0000 & 60.0000 & 53.0000 \\
\hline & 24.0000 & 54.0000 & 65.0000 & 53.0000 \\
\hline
\end{tabular}

Source: data processed with SPSS 2.4

\section{Test Instrument}

The instrument testing conducted in this study is the validity and reliability test. All questionnaires passed the validity test, with the calculated $r$ value greater than the rtable value. for the discipline variable with a total of all 11 statement items is 0.917 . Work environment variable with statement item 8 is 0.880 . The leadership style variable with statement item 10 is 0.903, while the employee performance variable with 13 statement items is 0.925 . In accordance with the description above, the Cronbach's Alpha coefficient value for all variables> 0.6 then thus all the variables in this study can be declared reliable.

\section{Classic assumption test}

To be able to do testing with multiple linear regression, the classical assumption test is first performed which consists of: normality test, multicollinearity test, and heteroscedasticity test. The normality test used in this study is by looking at the histogram graph, the normal probability plot, and using the One Sample

Klogorov-Smirnov test to find out whether the distribution of residuals is normally distributed or not. The results of the three tests are known that the data are normally distributed. The histogram graphs form a bell, and the NormalProbability Plot which shows that the data used is around a normal line. In the One Sample Klogorov-Smirnov test obtained a significance value greater than 0.05 , which means the residual value is normally distributed.

Multicollinearity test aims to test whether the regression model found a correlation between independent variables. A good regression model should have no correlation between independent variables. Multicollinearity tests use the amount of VIF (Variance Inflation Factor). Obtained results in the absence of multicollinearity problems in the studied variables. The basis for decision making is the amount of VIF and tolerance.

Heterokedastisitas test aims to test whether in the regression model there is a variance in variance from the residuals of one observation to another. The test results in this study are presented in the figure below: 


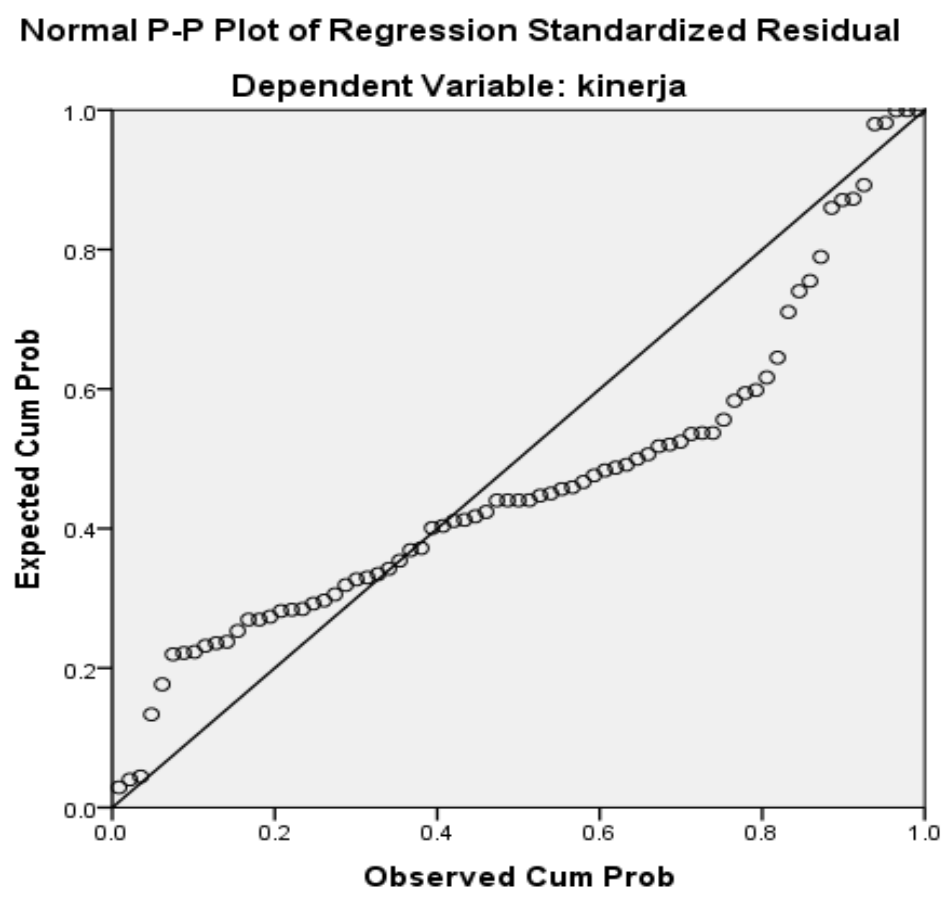

Figure 2. Heteroskedesticity Test Results

Based on the picture above, it can be concluded that in this study, heteroscedasticity did not occur in the regression model. Through the three tests above it is known that the regression model in this study is feasible to use.

\section{Multiple Linear Regression Analysis}

Based on the results of data processing, obtained by the multiple linear regression equation: $\mathrm{Y}=-0.094+0.228 \mathrm{X} 1-0.07 \mathrm{X} 2+0.785 \mathrm{X} 3+\mathrm{e}$

The constant value $=-0.094$ can be interpreted if all independent variables (leadership, compensation, and commitment) are considered constant or unchanged, the employee's performance is -0.094 . Constant value -0.094 results from multiple linear regression, here the value of $\mathrm{Y}=0.315 \mathrm{X} 1+0.219 \mathrm{X} 2+0.324 \mathrm{X} 3$

a) The leadership variable regression coefficient of 0.315 means that if leadership decreases by one unit, then the performance of the Pasar Mobil Kemayoran Management employees will decrease by 0.315 units assuming the other independent variables are of fixed value. The calculated $\mathrm{Sig}=0.315$ is greater than 0.05 , this indicates a significant positive

b) The compensation variable regression coefficient of 0.219 means that if the compensation increases by one unit, then the performance of the Pasar Mobil Kemayoran Management employee will increase by 0.219 units assuming the other independent variables are of fixed value. The calculated $\mathrm{Sig}=0.219$ shows that this is significant

c) The commitment variable regression coefficient of 0.324 means that if leadership has decreased by one unit, then the performance of employees will decrease by 0.324 units assuming the other independent variables are of fixed value. The result of sig $=0.324$ is greater than 0.05 , this shows a significant positive, the highest $\mathrm{X} 3$ coefficient, this shows the policy priorities to improve employee performance. 
d) $\mathrm{F}$ value $=11,644$, sig $=0,000$, this shows that simultaneously $\mathrm{X} 1, \mathrm{X} 2$ and $\mathrm{X} 3$ significantly influence the performance $(Y)$.

\section{Partial Test (t test)}

$\mathrm{T}$ test or partial test is used to see the effect caused by each independent variable that can be described through the table below:

Table 2. Partial Test ( $t$ test)

\section{Coefficients}

\begin{tabular}{|c|c|c|c|c|c|c|c|c|}
\hline \multirow{6}{*}{1} & & $\begin{array}{l}\text { UnstaI } \\
\text { Coe }\end{array}$ & $\begin{array}{l}\text { ardized } \\
\text { cients } \\
\text { Std. }\end{array}$ & $\begin{array}{c}\text { Standar } \\
\text { ed } \\
\text { Coefficie }\end{array}$ & & & $\begin{array}{r}\text { Colli } \\
\text { Sta } \\
\text { Tolera }\end{array}$ & $\begin{array}{l}\text { arity } \\
\text { tics }\end{array}$ \\
\hline & Model & B & Error & Beta & t & Sig. & e & VIF \\
\hline & (Constant) & 41301 & 2,126 & & 19,426 & .000 & & \\
\hline & leadership & .251 & .081 & .315 & 3,122 & .003 & .929 & 1,076 \\
\hline & Compensation & .045 & .021 & .219 & 2,167 & .034 & 922 & 1,085 \\
\hline & commitment & .064 & .019 & .324 & 3,295 & .002 & 974 & 1,026 \\
\hline
\end{tabular}

Dependent Variable: performance

Source: data processed with SPSS 2.4

\section{Simultaneous Test (F Test)}

The $\mathrm{F}$ test is used to determine the effect of the independent variables together (simultaneously) on the dependent variable. This study found that the Fcount value was 11,644 greater than the Ftable value of 2.38 with a value of sig. $0,000<0.05$ then $\mathrm{H} 0$ is rejected and $\mathrm{Ha}$ is accepted, so it can be concluded that the commitment variables (X1), compensation (X2) and leadership (X3) together or simultaneously affect the performance of employees (Y).

Table 3. Simultaneous Significance Test Results

\begin{tabular}{|c|c|c|c|c|c|c|}
\hline \multicolumn{7}{|c|}{ ANOVA a } \\
\hline & Model & Sum of Squares & Df & Mean Square & F & Sig. \\
\hline \multirow[t]{3}{*}{1} & Regression & 40,555 & 3 & 13518 & 11,644 & $.000 \mathrm{~b}$ \\
\hline & Residual & 82,431 & 71 & 1,161 & & \\
\hline & Total & 122,987 & 74 & & & \\
\hline
\end{tabular}

a. Dependent Variable: performance

Predictors: (Constant), leadership, compensation, commitment

Source: data processed with SPSS 2.4

\section{Determination Coefficient Test $\left(\mathbf{R}^{2}\right)$}

The coefficient of determination test (R2) is carried out to measure the extent of the ability of the leadership variable, compensation and commitment in explaining variations of employee performance variables. This research got the result of 0.568 ,

this explains that the contribution given by leadership, compensation and commitment to employee performance is $56.8 \%$ while the remaining $43.2 \%$ is influenced by other factors not examined. 
Table 4. Determination Coefficient Test $\left(\mathbf{R}^{2}\right)$

\begin{tabular}{|c|c|c|c|c|}
\hline \multirow[b]{2}{*}{ Model } & \multicolumn{3}{|c|}{ Model Summary b } & \multirow{2}{*}{$\begin{array}{c}\text { Std. Error of the } \\
\text { Estimate }\end{array}$} \\
\hline & $\mathbf{R}$ & R Square & Adjusted R Square & \\
\hline 1 & $.574 a$ & .330 & .301 & 1.07750 \\
\hline
\end{tabular}

a. Predictors: (Constant), leadership, , compensation, commitment

Dependent Variable: performance

Source: data processed with SPSS 2.4

\section{DISCUSSION AND RESEARCH RESULTS}

Based on the results of research conducted between independent variables (leadership, commitment, and compensation) to the dependent variable (employee performance) the Pasar Mobil Kemayoran Management obtained the following results:

\section{Analysis of the Effect of Leadership on Performance}

Based on the results of the $t$ test, the performance variable is known that performance has a significant effect on performance. Thus the results of testing the hypothesis states that Ho is rejected and $\mathrm{H} 1$ is accepted, so the first hypothesis stating that leadership influences performance is accepted. This can be interpreted that with the opportunity in terms of leadership in the Pasar Mobil Kemayoran Management has an impact on employee performance. However, what needs to be a concern, to support the intended leadership, the company should have a strategic initiative and timeline to ensure that leadership towards employees runs continuously and in line with what has been established by the company.

In accordance with the results of Leadership research in line with previous research Thesis with the title "The Effect of Leadership, Work Motivation And Work Discipline On Employee Performance of PT. Bank XYZ Area Depok "Writer Wulan Sari Utami Hasanah Master of Management Study Program Postgraduate Program in Mercu Buana University in 2018. Thus the results of the study reinforce the existing leadership theory.

\section{Analysis of the Effect of Commitment on Performance}

Based on the results of the research test the commitment variable is known that work commitment has significant and significant effect on performance. Thus the results of testing the hypothesis states that Ho is rejected and $\mathrm{H} 1$ is accepted, so the first hypothesis stating that commitment influences employee performance is accepted. This can be interpreted that the commitment factor in the Pasar Mobil Kemayoran Management can have implications for improving employee performance.

In accordance with the results of research Commitment in line with previous research Thesis with the title "The Effect of Leadership, Work Motivation and Organizational Commitment on Employee Performance of PT. Baruna Raya Logistic, Balikpapan, "Author Billy Andang Baruna, Master of Management, Postgraduate Program, Mercu Buana University in 2019. Thus the results of the study reinforce the existing commitment theory.

\section{Compensation Analysis of Performance}

Based on the research test results on the compensation variable, it is known that compensation has significant effect on performance. Thus the results of hypothesis testing stated Ho was rejected and $\mathrm{H}_{1}$ accepted so that the first hypothesis stating that compensation affects 
performance is accepted. This can be interpreted that with the compensation applied by the Pasar Mobil Kemayoran Management implies an increase in employee performance.

In accordance with the results of research Commitment in line with previous research Thesis with the title "The Effect of Work Motivation, Career Development and Compensation on Employee Performance Case Study of PT. Cibaliung Resources a subsidiary of PT. Antam Tbk "Author Sarifudin Tomi Inaku Master of Management Study Program Postgraduate Program in Mercu Buana University in 2018. Thus the results of the study reinforce the existing compensation theory.

\section{CONCLUSION}

Based on the results of the analysis and discussion, then it is concluded as follows:

1) Leadership has a significant positive effect on employee performance. Leadership is the ability to give constructive influence to others to make a cooperative effort to achieve the planned goals. The role of supervision in terms of providing motivation to the organizational structure underneath has a significant effect so that it impacts both employee performance

2) Compensation has a positive effect significant effect on employee performance.

3) Commitment has a significant positive effect on performance with the highest coefficient on employee performance thereby encouraging employee work to the maximum so as to create a good work ethic from employees and impact loyal employees to the company.

Based on the results of the study and the conclusions obtained from the research that has been done, the following are suggestions that the authors can convey in this study, which are as follows:

1) Pasar Mobil Kemayoran Management to create a more comfortable atmosphere at work and establish a harmonious relationship between employees so that each other can cooperate with each other, especially between subordinates and superiors.

2) Pasar Mobil Kemayoran Management provides rewards or rewards to employees whose performance results are good.

3) Pasar Mobil Kemayoran Management wants to provide opportunities for employees to come up with their bright and constructive ideas for the company's progress in the future.

4) Pasar Mobil Kemayoran Management wants to provide opportunities for promotion in accordance with employee performance.

5) Pasar Mobil Kemayoran Management evaluates the performance of employees who can complete on time in carrying out the tasks and obligations given.

\section{BIBLIOGRAPHY}

AA. Anwar Prabu Mangkunegara, 2013, Manajemen Sumber Daya Manusia Perusahaan, Remaja Rosdakarya, Bandung.

Amstrong, M dan Baron, A. (1998). Performance Management - The New Realities. Institute of Personel and Development, London.

Abdullah, M. 2014. Manajemen dan Evaluasi Kinerja Karyawan. Yogyakarta: Aswaja Pressindo.

Arikunto, Suharsimi. (2006). Prosedur Penelitian Suatu Pendekatan Praktik. Rineke Cipta. Jakarta.

Bangun, Wilson. (2012). Manajemen Sumber Saya Manusia. Erlangga. Jakarta

Bauer. 2014. Strategic Management (Competitiveness \& Globalization). Journal of Competitiveness.

Ghozali, Imam. (2016). Aplikasi Analisis Multivariate Dengan Program SPSS. Penerbit Universitas Diponegoro. Semarang.

Hasibuan, Malayu. (2012). Manajemen Sumber Daya Manusia. PT. Bumi Aksara. Jakarta.

Mangkunegara. (2017). Manajemen Sumber Daya Perusahaan. PT. Remaja Rosda Karya. Bandung 
Masyhudzulhak. Ahmad Badawi Saluy. (2018) Pelatihan SPSS dan PLS untuk Skripsi dan Tesis. Program Pascasarjana Magister Manajemen. Universitas Mercu Buana. Jakarta.

Moeheriono. 2012. Pengukuran Kinerja Berbasis Kompetensi. Edisi Revisi. Jakarta. PT. Raja Grafindo Persada.

Rivai.(2011). Sumber Daya Manusia Untuk Perusahaan.Rajawali Pers. Jakarta.

Rivai, Veithzal. 2009. Manajemen Sumber Daya Manusia Untuk Perusahaan Dari Teori ke Praktik. Jakarta: Raja Grafindo Persada

Robbins, Stephen P. dan Timothy A. Judge.(2013). Organizational Behavior15th Edition. Pearson Education. Boston.

Sugiyono.(2014). Metode Penelitian Pendidikan Kuantitatif, Kualitatif dan R\&D. Alfabeta. Bandung.

Siagian, Sondang P. 2006, Manajemen Sumber Daya Manusia, cetakan kelima belas, Jakarta: PT Bumi Aksara.

List of Website :

http://organisasi.org/definisi_pengertian_tugas_fungsi_manajemen_sumber_ daya_manusia_sdm_ilmu_ekonomi_manajemen_manajer_msdm

http://www.google.com/

http://www.portalhr.com/kolom/2id23.html

http://www.psikologizone.com/peran-manajemen-sumber-daya-manusia

http://jurnal-sdm.blogspot.com/2009/07/fungsi-dan-peran-manajemen-sumber-daya.html

http://iimrsch.wordpress.com/2009/10/12/peran-manajemen-sumber-daya-manusia-dalam-organisasi/

http://opinionpublikator.blogspot.com/2010/02/peran-strategis-manajemen sumber-daya.html

http://www.propotenzia.com/2010/09/peran-strategis-pengembangan-sdm/ 